\title{
Simultaneous anterior cervical repair of type IV laryngeal cleft and tracheo-oesophageal fistula
}

\author{
Gargi Pandey, James Rudd (1) , Sevasti Konstantinidou, Colin Butler
}

ENT, Great Ormond Street Hospital for Children NHS Foundation Trust, London, UK

\section{Correspondence to} Dr Gargi Pandey; gargi.pandey@nhs.net

Accepted 8 December 2021

\section{DESCRIPTION}

A boy with antenatal polyhydramnios, born at 38 weeks via normal vaginal delivery, required prompt intubation due to cyanosis. Following successful extubation onto high-flow nasal cannula (HFNC), he was transferred to a tertiary paediatric ICU for management of lung collapse and pneumonia. Microlaryngoscopy and bronchoscopy (MLB) identified a $3 \mathrm{~cm}$ posterior laryngeal cleft (LC) with a pit connecting the trachea to oesophagus at the midpoint between the distal cleft and carina (tracheo-oesophageal fistula, TOF). He was noted to have dysmorphic features; hypertelorism and hypospadias prompting genetic testing, confirming Opitz G/BBB syndrome.

At 9 days, he was transferred to a quaternary centre. Repeat MLB confirmed a type IV LC (figure 1), H-type TOF $1 \mathrm{~cm}$ superior to the carina and $0.9 \mathrm{~cm}$ from the cleft (figure 2) with distal tracheobronchomalacia. The repair of LC and TOF was performed simultaneously via an anterior cervical approach. The airway was entered anterior to the length of the cleft via a midline incision. The TOF was repaired with a double-layer closure, with simultaneous closure of the oesophageal mucosa superior and inferiorly, trachealis, tracheal mucosa and anterior tracheal wall. Admission continued on paediatric intensive care unit (PICU) (73 days) with transfer back to the local hospital once extubated onto HFNC.

Type IV LC is believed to be a result of incomplete fusion of the tracheo-oesophageal septum distal to the cricoid cartilage. ${ }^{1}$ The Benjamin and Inglis classification is most common. Type I cleft is above the vocal folds (most common), type II extends below, type III extends through the cricoid cartilage with/without extension into trachea

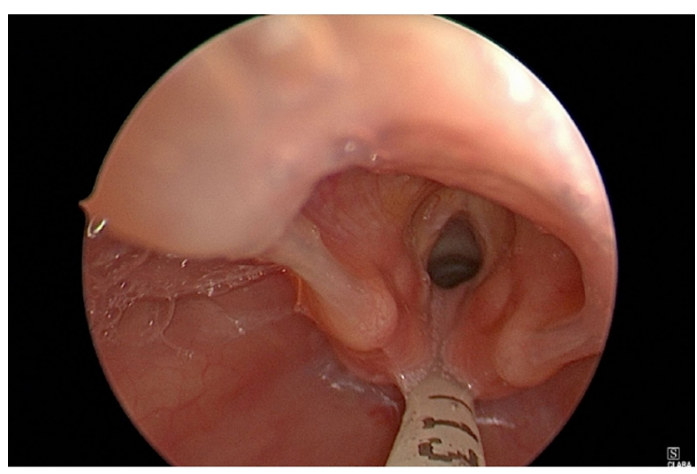

Figure 1 Type IV laryngeal cleft with correctly sited endotracheal tube protruding posteriorly into the oesophagus.

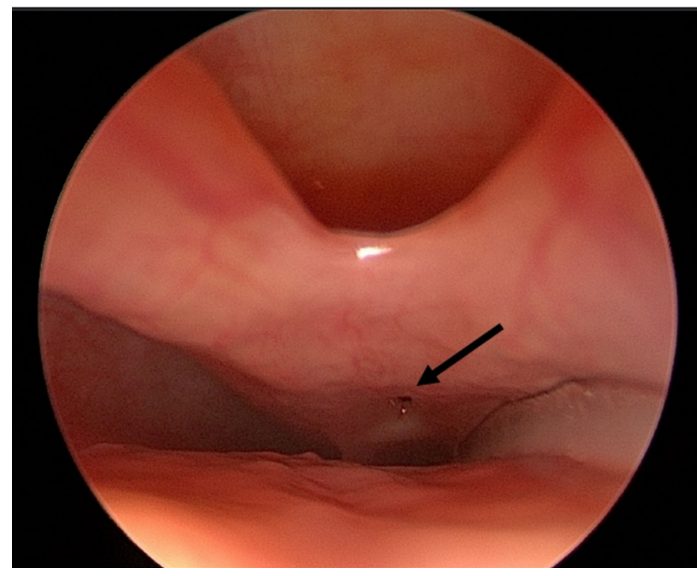

Figure 2 Type 4 laryngeal cleft with type H TOF visible distal to the cleft.

and type IV extends into thoracic trachea (least common). ${ }^{2}$ Symptoms range from asymptomatic to varying degrees of dysphagia, aspiration and stridor in type I, to respiratory failure in type IV, depending on severity of the cleft. ${ }^{1} \mathrm{LC}$ accounts for $0.2-1.5 \%$ of congenital laryngeal abnormalities. The gold standard for diagnosis is MLB. ${ }^{3}$ They are associated with other congenital abnormalities (laryngomalacia and TOF) and syndromes (Opitz G syndrome and VACTERL). ${ }^{4}$ TOF has an incidence of approximately 1 in 3500 live births; it is confirmed with contrast studies or bronchoscopy. ${ }^{5}$ Type-H TOF (without oesophageal atresia) accounts for only 3\% of these. Presentation includes cyanotic episodes and respiratory distress due to aspiration. ${ }^{6}$ The incidence of TOF in children with LC is unknown. However, there are reports of an association in $12-45 \%$ cases. $^{7-9}$

Opitz $\mathrm{G} / \mathrm{BBB}$ is a congenital disorder affecting midline structures; it is characterised by craniofacial, genitourinary and laryngotracheo-oesophageal defects. ${ }^{10}$ VACTERL is defined by the presence of three of the following: vertebral defects, anal atresia, cardiac defects, TOF and renal and limb abnormalities. $^{11}$

Type IV LC is most commonly repaired via anterior laryngotomy, avoiding damage to neurovascular structures. ${ }^{12}$ Standard repair of proximal TOF is via lateral cervicotomy. ${ }^{13} 14$ For distal TOF, thoracotomy is preferred. ${ }^{15}{ }^{16}$ Cohen presents a case of combined repair via lateral pharyngotomy. ${ }^{17}$ We present a case of a combined repair of a type IV LC and type-H TOF via the anterior approach, not previously reported, in a child with Opitz G syndrome. 


\section{Patient's perspective}

As a new mother, I found the experience very difficult. Due to the COVID-19 pandemic, only one parent was permitted to be with patients. I found it very difficult to deal with it all alone especially as I was far from home. However, the staff were very helpful. Since being discharged, I feel he has been very well and one wouldn't think there had been any problems other than having two scars.

\section{Learning points}

- Type I clefts can often go undiagnosed due to symptoms suggestive of more common pathologies. Whereas type III or IV clefts usually present in the first few days of life.

- A high index of suspicion is required for a tracheooesophageal fistula (TOF) in children with laryngeal clefts (LC) as they can co-exist resulting in worsening symptoms. We may consider future classifications of TOF to include LC.

- We advocate formal assessment with microlaryngoscopy and bronchoscopy at a tertiary paediatric centre for children with suspected LC.

Contributors The responsible consultant for the patient was $C B$. The patient was cared for by Dr GP, SK and JR.

Funding The authors have not declared a specific grant for this research from any funding agency in the public, commercial or not-for-profit sectors.

Competing interests None declared.

Patient consent for publication Consent obtained from parent(s)/guardian(s)

Provenance and peer review Not commissioned; externally peer reviewed.

Case reports provide a valuable learning resource for the scientific community and can indicate areas of interest for future research. They should not be used in isolation to guide treatment choices or public health policy.
ORCID iD

James Rudd http://orcid.org/0000-0002-9976-2376

\section{REFERENCES}

1 Johnston DR, Watters K, Ferrari LR, et al. Laryngeal cleft: evaluation and management. Int J Pediatr Otorhinolaryngol 2014;78:905-11.

2 Leboulanger N, Garabédian E-N. Laryngo-tracheo-oesophageal clefts. Orphanet J Rare Dis 2011;6:81.

3 Griffith CL, Liversedge TFG. Laryngeal clefts. BJA Educ 2015; 15:237-42.

4 Jesse C, Jonathan S, Jeremy N, Chen J, Stern J, Neuman J, et al. A rare case of laryngeal cleft in association with VACTERL and malrotation. Radiol Case Rep 2019:14:315-9.

5 Depaepe A, Dolk H, Lechat MF. The epidemiology of tracheo-oesophageal fistula and oesophageal atresia in Europe. EUROCAT Working group. Arch Dis Child 1993;68:743-8.

6 Donnelly P, McVea S, Flannigan C, et al. Incidental diagnosis of an H-type tracheooesophageal fistula. BMJ Case Rep 2016;2016. doi:10.1136/bcr-2016-215419. [Epub ahead of print: 29 Jun 2016].

7 Rahbar R, Rouillon I, Roger G, et al. The presentation and management of laryngeal cleft: a 10-year experience. Arch Otolaryngol Head Neck Surg 2006;132:1335-41.

8 Evans KL, Courteney-Harris R, Bailey CM, et al. Management of posterior laryngeal and laryngotracheoesophageal clefts. Arch Otolaryngol Head Neck Surg 1995;121:1380-5.

9 Fraga JC, Adil EA, Kacprowicz A, et al. The association between laryngeal cleft and tracheoesophageal fistula: myth or reality? Laryngoscope 2015;125:469-74.

10 Tajima H, Itoh H, Mochizuki A, et al. Case of polyhydramnios complicated by Opitz G/ BBB syndrome. J Obstet Gynaecol Res 2010;36:876-81.

11 Solomon BD. VACTERL/VATER association. Orphanet J Rare Dis 2011;6:56

12 Walner DL, Stern Y, Collins M, et al. Does the presence of a tracheoesophageal fistula predict the outcome of laryngeal cleft repair? Arch Otolaryngol Head Neck Surg 1999;125:782-4.

13 Genty E, Attal P, Nicollas R, et al. Congenital tracheoesophageal fistula without esophageal atresia. Int J Pediatr Otorhinolaryngol 1999;48;)::231-8. 25;.

14 Riazulhaq M, Elhassan E. Early recognition of $\mathrm{H}$-type tracheoesophageal fistula. APSP J Case Rep 2012;3:4.

15 Ou P, Seror E, Layouss W, et al. Definitive diagnosis and surgical planning of $\mathrm{H}$-type tracheoesophageal fistula in a critically ill neonate: first experience using air distension of the esophagus during high-resolution computed tomography acquisition. J Thorac Cardiovasc Surg 2007;133:1116-7.

16 Crabbe DCG. Isolated tracheo-oesophageal fistula. Paediatr Respir Rev 2003;4:74-8.

17 Cohen SR. Cleft larynx. a report of seven cases. Ann Otol Rhinol Laryngol 1975;84:747-56

Copyright 2021 BMJ Publishing Group. All rights reserved. For permission to reuse any of this content visit https://www.bmj.com/company/products-services/rights-and-licensing/permissions/

BMJ Case Report Fellows may re-use this article for personal use and teaching without any further permission.

Become a Fellow of BMJ Case Reports today and you can:

- Submit as many cases as you like

- Enjoy fast sympathetic peer review and rapid publication of accepted articles

- Access all the published articles

- Re-use any of the published material for personal use and teaching without further permission

Customer Service

If you have any further queries about your subscription, please contact our customer services team on +44 (0) 2071111105 or via email at support@bmj.com.

Visit casereports.bmj.com for more articles like this and to become a Fellow 